


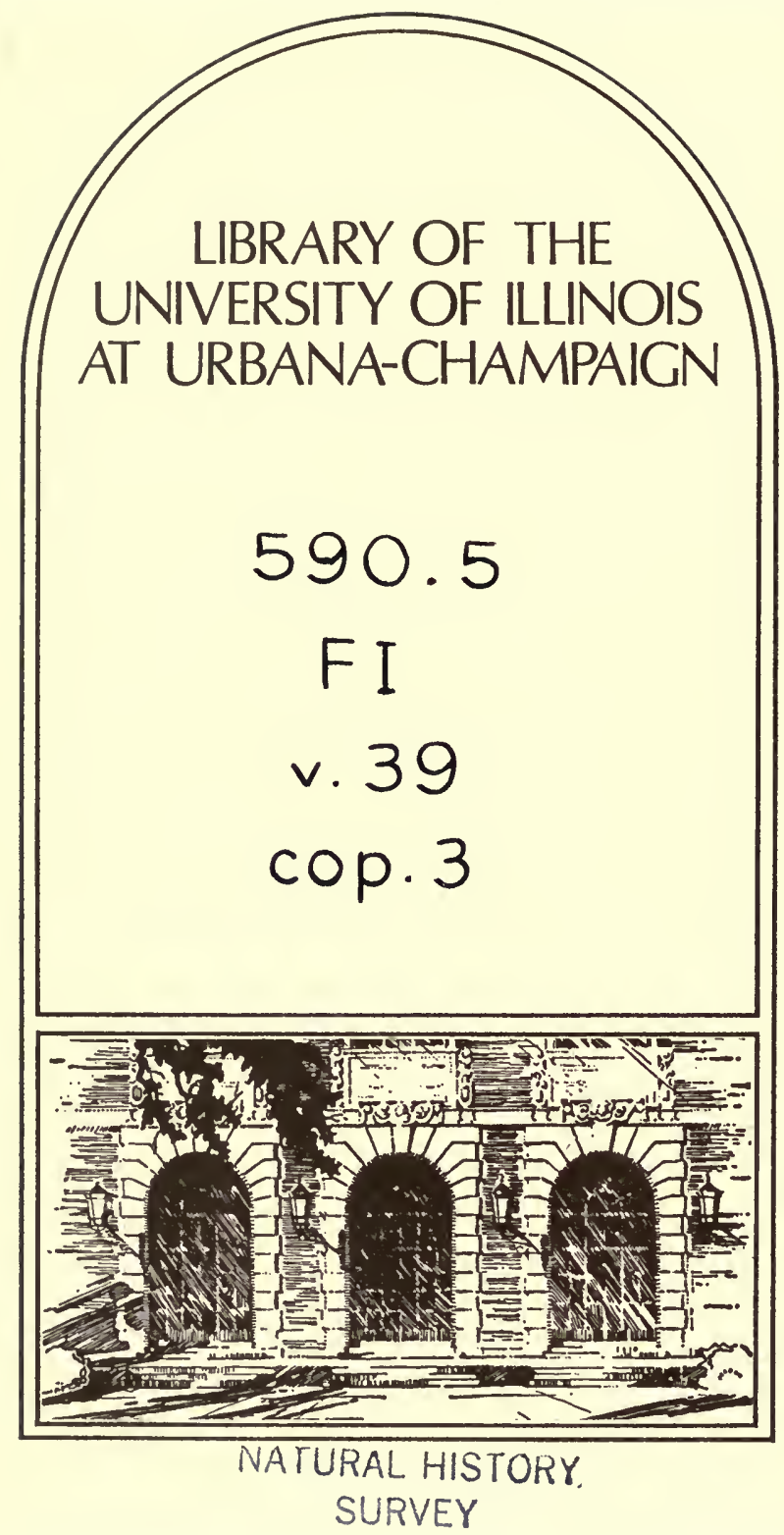








\title{
FIELDIANA: ZOOLOGY
}

\author{
A continuation of the \\ ZOOLOGICAL SERIES \\ of
}

FIELD MUSEUM OF NATURAL HISTORY

VOLUME 39

NATURAL HISTORY SURVEY

FEB 111971

IIRRARY

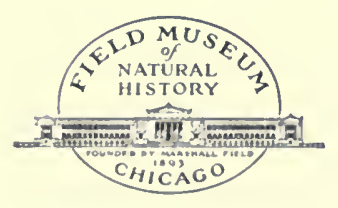

FIELD MUSEUM OF NATURAL HISTORY

CHICAGO, U.S.A. 



\title{
FIELDIANA · ZOOLOGY
}

Published by

CHICAGO NATURAL HISTORY MUSEUM

Deep Sea Fishes from the Gulf of Mexico With the Description of a New Species

Squalogadus intermedius (Macrouroididae)

\author{
MARION GREY \\ Associate, Division of Fishes
}

The extensive exploration undertaken in the Gulf of Mexico in recent years by the United States Fish and Wildlife Service has at times reached deep water, and some of the fishes collected have been sent to Chicago Natural History Museum for identification. Among these are a new species of Squalogadus, several new records for the Gulf of Mexico and the western Atlantic, and some forms rarely caught and therefore deserving of notice.

The figures are the work of the following artists: Miss Carolyn Reusch, Mr. Tom Dolan, and Mr. John Pfiffner, Staff Artist of Chicago Natural History Museum.

\section{Family MYXINIDAE}

Paramyxine springeri Bigelow and Schroeder

One specimen. Station 1006, $24^{\circ} 20^{\prime}$ N., $83^{\circ} 20^{\prime}$ W., April 13, 1954, in 190 fathoms (348 meters).

\section{Family SCYLIORHINIDAE}

Apristurus riveri Bigelow and Schroeder

One specimen, $276 \mathrm{~mm}$. Station $1426,29^{\circ} 07^{\prime} \mathrm{N}$., $87^{\circ} 54^{\prime} \mathrm{W}$., September 24, 1955, in 600 fathoms (1098 meters).

Previously known only from the type, taken off the north coast of Cuba (ca. $23^{\circ} \mathrm{N} ., 80^{\circ} \mathrm{W}$.) in 580 fathoms (1060 meters).

Library of Congress Catalog Card Number: 59-10696

No. 872

323 
Pristiurus arae Nichols

Two specimens, male, 263 and $230 \mathrm{~mm}$. Station $1016,24^{\circ} 22^{\prime} \mathrm{N}$., $83^{\circ} 18^{\prime}$ W., April 16, 1954, in 200 fathoms (366 meters).

\section{Family SQUALIDAE}

Etmopterus virens Bigelow, Schroeder and Springer

One specimen, female, $236 \mathrm{~mm}$., and two specimens, male, 208 and $194 \mathrm{~mm}$. Station $1565,29^{\circ} 11^{\prime} \mathrm{N} ., 88^{\circ} 02^{\prime}$ W., June 22, 1956, in 240 fathoms (438 meters).

\section{Family TORPEDINIDAE}

Benthobatis marcida Bean and Weed

One specimen, ca. $100 \mathrm{~mm}$. Station $1342,23^{\circ} 10^{\prime} \mathrm{N} ., 79^{\circ} 33^{\prime} \mathrm{W}$., July 16, 1955, in 280 fathoms (512 meters).

\section{Family RAJIDAE}

Breviraja sinus-mexicana Bigelow and Schroeder

Fourteen specimens, $147-322 \mathrm{~mm}$. Station $379,28^{\circ} 53^{\prime} \mathrm{N}$., $88^{\circ} 44.5^{\prime} \mathrm{W}$., June 7, 1951, in 260-280 fathoms (475-512 meters).

One specimen, $327 \mathrm{~mm}$. Station $795,29^{\circ} 15^{\prime} \mathrm{N} ., 87^{\circ} 49^{\prime} \mathrm{W}$., June 12, 1953, in 230-300 fathoms (421-549 meters).

\section{Family GHIMAERIDAE}

Hydrolagus alberti Bigelow and Schroeder

Four specimens, $135-181 \mathrm{~mm}$. to front of upper caudal fin. Station $1565,29^{\circ} 11^{\prime} \mathrm{N} ., 88^{\circ} 02^{\prime} \mathrm{W}$., June 22,1956 , in 240 fathoms (438 meters)

One specimen, $175 \mathrm{~mm}$. to front of upper caudal fin. Station 1568 , $29^{\circ} 09^{\prime}$ N., $88^{\circ} 12^{\prime}$ W., June 23,1956 , in 250 fathoms (457 meters).

Three specimens, $155-194 \mathrm{~mm}$. to front of upper caudal fin. Station $1569,29^{\circ} 11^{\prime}$ N., $88^{\circ} 02^{\prime}$ W., June 23,1956 , in 250 fathoms (457 meters).

Four specimens, $123-173 \mathrm{~mm}$. to front of upper caudal fin. Station $1571,29^{\circ} 10^{\prime}$ N., $88^{\circ} 07^{\prime}$ W., June 23, 1956, in 250 fathoms (457 meters). 


\section{Hydrolagus mirabilis (Collett)}

Two specimens, length to front of upper caudal fin 410 and $300 \mathrm{~mm}$. Station $1426,29^{\circ} 07^{\prime}$ N., $87^{\circ} 54^{\prime}$ W., September 24,1955 , in 600 fathoms (1098 meters).

The larger specimen, total length ca. $432 \mathrm{~mm}$. including short remainder of caudal filament, is a mature male, the smaller one an immature male (total length ca. $451 \mathrm{~mm}$., caudal filament not complete). Both fishes are in poor condition but agree well with the detailed description given by Holt and Byrne (1910, p. 11), differing only in that the preorbital loop of the infraorbital sensory canal is larger and more angular than shown in the figure (op. cit., pl. 2), and the vertical fins are uniform dark brown, without the white base described in eastern Atlantic specimens.

$H$. mirabilis is new to the western Atlantic fauna, having been caught previously only from Faroe Bank, the Faroe-Shetland Channel, and south to southwestern Ireland. Its center of distribution vertically is below 900 meters, its certain depth range 698 to 1418 1454 meters.

\section{Family ALEPOCEPHALIDAE}

\section{Rouleina attrita (Vaillant)}

One specimen, male, standard length $328 \mathrm{~mm}$. Station 1302, $28^{\circ} 53^{\prime}$ N., $87^{\circ} 58^{\prime}$ W., May 26, 1955, in 890 fathoms (1628 meters).

Description.-Dorsal rays 19; anal damaged, incomplete; pectoral 7; ventral 6. Lateral line ca. 50. Branchiostegal rays 5 . Gill rakers $15+7$. Pyloric caecae 9 .

Measurements in millimeters, followed in parentheses by percentage of the standard length (ca. $328 \mathrm{~mm}$.): Depth ca. 62.5 (ca. 19.4); head 102 (31.2); snout 26.5 (8.1); orbit 22 (6.7); interorbital width 17 (5.2); upper jaw 52 (15.8); tip of snout to origin of dorsal ca. 209 (ca. 64.0), to origin of anal ca. 219 (ca. 65.0), to ventral base ca. 149 (ca. 45.5); distance between ventral base and anal fin ca. 63 (ca. 19.2); least depth of caudal peduncle ca. 22 (6.7).

Specimen badly damaged, skin mostly lost, anal fin partially lost, the first 13 or 14 rays still present. Tip of symphyseal knob broken. Upper jaw reaching posterior margin of orbit. Teeth uniserial, small, those of maxillary slightly smaller and less numerous than those on premaxillary. Gill rakers denticulate on inner edge. A series of large pores between eye and maxillary. Lateral line prominent, a tube of deep-black skin supported by a series of about 50 ring-like scales. 
Color of head, and probably of body also, black. Linings of mouth and gill covers, and peritoneum, black.

Remarks. - R. attrita (syn., Bathytroctes mollis Koehler) is new to the fauna of the western Atlantic. The species is an inhabitant of very deep water and until now has been caught only in the eastern Atlantic, from the Azores and the Gulf of Gascony south to Cape Verde, at depths between 1442 and 3655 meters.

\section{Xenodermichthys socialis Vaillant}

One specimen, standard length $140.5 \mathrm{~mm}$. Station $597,29^{\circ} 13^{\prime} \mathrm{N}$., $87^{\circ} 59^{\prime}$ W., July 10,1952 , in 280 fathoms (512 meters).

Many recent authors have applied to this species the name $X$.copei (Gill). The name Aleposomus copei was mentioned by Gill (1884, p. 433) but the type was neither described nor figured until 1895 (Goode and Bean, 1895, p. 47, fig. 51). The original name was therefore a nomen nudum and as such has no taxonomic status. $X$. socialis was described by Vaillant in 1888 .

This specimen was listed by Springer and Bullis (1956, p. 48) as I originally identified it, $X$. copei.

\section{Family GONOSTOMATIDAE}

Gonostoma elongatum Günther

Seven specimens, total lengths ca. 55 and 130-210 mm. Station $796,29^{\circ} 10^{\prime} \mathrm{N}$., $87^{\circ} 55^{\prime} \mathrm{W}$., June 12,1953 , in $490-600$ fathoms (8961098 meters).

One specimen, standard length $131.5 \mathrm{~mm}$. Station $841,28^{\circ} 58^{\prime} \mathrm{N}$., $88^{\circ} 00^{\prime}$ W., October 6,1953 , in 830-930 fathoms (1518-1700 meters).

One specimen, standard length $130 \mathrm{~mm}$. Station $1028,28^{\circ} 28^{\prime} \mathrm{N}$., $87^{\circ} 18^{\prime} \mathrm{W}$., April 21, 1954, in 780 fathoms (1428 meters).

There is apparently no earlier record of $G$. elongatum from the Gulf of Mexico, although it is possible that Blake Station 38, one of the localities given for the species by Goode and Bean (1895, p. 102), may have been in the Gulf. These specimens were listed by Springer and Bullis (1956, p. 50).

\section{Family STERNOPTYGHIDAE}

\section{Sternoptyx diaphana Hermann}

One specimen, $26 \mathrm{~mm}$. Station $1019,24^{\circ} 16^{\prime} \mathrm{N} ., 83^{\circ} 22^{\prime} \mathrm{W}$., April 16, 1954, in 375 fathoms (685 meters). 
Two specimens, 32.5 and $15 \mathrm{~mm}$. Station $1425,29^{\circ} 04^{\prime} \mathrm{N}$., $88^{\circ} 05^{\prime}$ W., September 24, 1955, in 500 fathoms (914 meters).

\section{Family CHAULIODONTIDAE}

\section{Chauliodus sloanei Bloch and Schneider}

One specimen, $151 \mathrm{~mm}$. (without caudal). Station $1541,24^{\circ} 28^{\prime} \mathrm{N}$., $83^{\circ} 29^{\prime} \mathrm{W}$., June 15, 1956, in 220 fathoms (403 meters).

Five specimens, $128-162 \mathrm{~mm}$. (without caudal). Station 1565, $29^{\circ} 11^{\prime}$ N., $88^{\circ} 02^{\prime}$ W., June 22, 1956, 240 fathoms (438 meters).

Two specimens, 135 and $146 \mathrm{~mm}$. (without caudal). Station 1569 . $29^{\circ} 11^{\prime} \mathrm{N}$., $88^{\circ} 02^{\prime} \mathrm{W}$., June 23,1956 , in 250 fathoms (457 meters),

\section{Family MELANOSTOMIATIDAE}

\section{Bathophilus pawneei Parr}

One specimen, standard length ca. $120 \mathrm{~mm}$. Station $1418,27^{\circ} 52^{\prime} \mathrm{N}$., $90^{\circ} 44^{\prime}$ W., September 22, 1955, in 275 fathoms (503 meters).

One specimen, standard length $87 \mathrm{~mm}$. Station $1565,29^{\circ} 11^{\prime} \mathrm{N}$., $88^{\circ} 02^{\prime} \mathrm{W}$., June 22,1956 , in 240 fathoms (438 meters).

The species has been reported twice from the Gulf of Guinea in the eastern Atlantic, from numerous localities in the Caribbean Sea and in the central and western Atlantic, but not previously from the Gulf of Mexico.

\section{Leptostomias gladiator (Zugmayer)}

One specimen, standard length $215 \mathrm{~mm}$. Station $1425,29^{\circ} 04^{\prime} \mathrm{N}$., $88^{\circ} 05^{\prime}$ W., September 24,1955 , in 500 fathoms (914 meters).

Description.-Dorsal rays 20; anal 24; pectoral 10; ventral 7 . Photophores: IP 11, continuous with PV. PV ca. 40. VA 22, the last four above anal fin. AC 13. Lateral series 39 to ventral, 20 beyond ventral. Minute photophores all over head, including a ring around edge of eyeball, and also on body where skin remains. No post-orbital light organ.

Measurements in millimeters: Depth 18.5; head 25.5; snout 7.5; eye 4.5; upper jaw 16.5; lower jaw 16.5; barbel ca. 92 . Tip of barbel bulb folded over and ending in three small finger-like processes, the middle one the largest.

Remarks. - L. gladiator was described by Zugmayer (1911, p. 5) from a specimen caught in the eastern Atlantic, ca. $44^{\circ} \mathrm{N} ., 11^{\circ} \mathrm{W}$. 
Roule and Angel (1933, p. 17) reported a second specimen from ca. $30^{\circ}$ N., $25^{\circ}$ W., and recently Koefoed $(1956$, p. 9$)$ has recorded one from off Portugal. Beebe and Crane (1939, p. 127) reported twenty specimens taken off Bermuda and synonymized with gladiator the species L. ramosus Regan and Trewavas $(1930$, p. 61) and Melanostomias problematicus Parr (1927, p. 46), known from various parts of the central Atlantic and off the Bahama Islands. The number of pectoral rays of the Bermuda specimens was not given. According to Zugmayer the type of gladiator had only five pectoral rays. Parr's specimen, and those described by Regan and Trewavas, had ten. There are ten pectoral rays in the present specimen also, but Koefoed's example had only seven.

The genus Leptostomias has not been reported previously from the Gulf of Mexico. This specimen was recorded as $L$. ramosus by Springer and Bullis (1956, p. 49).

\section{Family BATHYPTEROIDAE}

\section{Bathypterois viridensis (Roule)}

One specimen, standard length ca. $78 \mathrm{~mm}$. Station $1425,29^{\circ} 04^{\prime} \mathrm{N}$., $88^{\circ} 05^{\prime}$ W., September 24,1955 , in 500 fathoms (914 meters).

The head of the specimen is severely damaged, the length given being approximate only. The dorsal count is 12 ; anal 11; ventral 8; and pectoral $2+8+5$ on the left side, $2+7+5$ on the right side. The outer ventral and lower caudal rays are greatly elongated and the anal origin is well in advance of the end of the dorsal. In color the body is generally pale, sprinkled with black. The abdomen, caudal fin, and undetermined portions of the head are black.

The species has been reported once before in the Gulf of Mexico, south of the Tortugas. It should be noted that the present specimen was listed by Springer and Bullis (1956, p. 55) and that their record of Benthosaurus grallator Goode and Bean from Station 1019 should be referred to Bathypterois viridensis (G. W. Mead, 1957, in litt.).

\section{Family SERRIVOMERIDAE}

\section{Platuronides ophiocephalus Parr}

One specimen, $590 \mathrm{~mm}$. (small piece of tail broken off). Station $1425,29^{\circ} 04^{\prime}$ N., $88^{\circ} 05^{\prime}$ W., September 24,1955 , in 500 fathoms (914 meters). 
Previously known only from the type, $632 \mathrm{~mm}$. long, from Bermuda, 2012 meters.

\section{Family MACROURIDAE}

\section{Steindachneria argentea Goode and Bean}

Four specimens, $270-288 \mathrm{~mm}$. Station $1565,29^{\circ} 11^{\prime} \mathrm{N}$., $88^{\circ} 02^{\prime} \mathrm{W}$., June 22,1956 , in 240 fathoms (438 meters).

\section{Trachonurus sulcatus Goode and Bean}

One specimen, total length $324+\mathrm{mm}$., small piece of tail lacking. Station $349,29^{\circ} 09^{\prime}$ N., $87^{\circ} 58^{\prime}$ W., May 22,1951 , in $470-500$ fathoms (860-914 meters).

Description.-Dorsal rays 10 ; pectoral 14; ventral 7; branchiostegal 7. Measurements expressed in percentages of total length (about $324 \mathrm{~mm}$.): Depth ca. 12.0; head ca. 16.0; snout to dorsal ca. 18.5; snout to anal ca. 24.4. Measurements in millimeters, figures in parentheses representing percentages of head length $(52 \mathrm{~mm}$.): Depth 40 (77.0); diameter of eye 13.5 (26.0); snout measured from eye 12 (23.1), measured from mouth, ventrally, ca. 8 (ca. 15.4); upper jaw 18.5 (35.6); interorbital width at center of eye 18.5 (35.6); barbel 3.5 (6.75); distance between anterior insertion of ventral to origin of anal $14(27.0)$; length of ventral ca. 15 (ca. 28.8); pectoral broken.

Anus about in center of a black scaleless area that extends from posterior insertion of ventrals to anal origin. Outer ventral ray slightly prolonged and filamentous. Ventral origin behind that of first dorsal, which is placed just behind pectoral base. First dorsal spine very small, second spine smooth, last ray of first dorsal fin short and delicate. Origin of second dorsal fin slightly behind anal origin.

Upper jaw with a band of villiform teeth, the outer row close-set and slightly enlarged. Lower jaw with a band of villiform teeth, more numerous and crowded anteriorly. No teeth on palatines or vomer.

Lower limb of second gill arch with nine tubercular gill rakers.

Color almost uniform dark brown, with the belly, branchiostegal membranes, mouth and opercular linings black.

Remarks. - T. sulcatus has not been reported in the western Atlantic since the nineteenth century, when the type was caught in the Gulf of Mexico (ca. $28^{\circ} \mathrm{N}$., $86^{\circ} \mathrm{W}$., in 420 fathoms) and a second specimen off Martinique (472 fathoms). T. asperrimus (Vaillant), from the eastern Atlantic, is probably a synonym. It has been taken 
off the Canary Islands, Morocco, and the Azores, at depths between 1098 and 1590 meters.

The specimen described here was recorded by Springer and Bullis (1956, p. 60).

\section{Family MACROUROIDIDAE}

Squalogadus intermedius, new species. Figure 53.

Holotype.-United States National Museum, no. 185606, 289+ mm. Station $1426,29^{\circ} 07^{\prime}$ N., $87^{\circ} 54^{\prime}$ W., September 24, 1955, in 600 fathoms (1098 meters).

Paratypes.-CNHM no. 64489 , five specimens, $259+$ to $287+\mathrm{mm}$. Same data.

Description.-Total length of holotype $289+\mathrm{mm}$., of paratypes $259+$ to $287+\mathrm{mm}$., all specimens, with possibly one exception, lacking tips of tails. Length from snout to anus 106-147.5 mm. (holotype $117 \mathrm{~mm}$.). Head and body soft and pliable, the following millimeter measurements of holotype perhaps not entirely accurate: Depth at ventral bases 58 ; body width 24.5 ; distance from ventral to anus 21.5 , to isthmus 14.5; length of head 97 ; diameter of orbit 10 ; interorbital width 42.5; length of snout 31 ; pre-oral length 40.5; length of upper jaw 23; diameter of nasal fossa 4 ; distance from orbit to nasal fossa 3.5; longest gill raker 6.5 .

Mouth inferior, its anterior edge beneath middle of eye. Rami of upper jaw separate. Teeth minute, in bands on jaws only; premaxillary bands broad in anterior half, very narrow posteriorly; mandibular bands uniformly narrow. Nostrils in a round naked area close to eye. Gill rakers long, their inner edges rough, 7-9 + 20-21 on first arch, longest (in holotype) ca. 1.5 in eye. No pseudobranchiae. Branchiostegal rays 7.

Vertical fins, especially anteriorly, encased in thick, translucent skin, tips of rays free. Dorsal origin above gill opening, first few rays short. First few anal rays equal in length to longest dorsal rays, other anal rays shorter than dorsal rays. Ventrals with five rays, small, broken, their insertion slightly in advance of pectoral bases. Pectorals small, rays 26. Anus just in front of anal fin. Scales small, with erect spinules, those of body nearly all lost, those of head mostly remaining. About twelve scales between lateral line and dorsal origin. A naked area behind pectoral. Scalation of under side of head uncertain, scales remaining along lower jaw in most specimens, pockets clear on gular membranes in some specimens but not in others. No scales or 


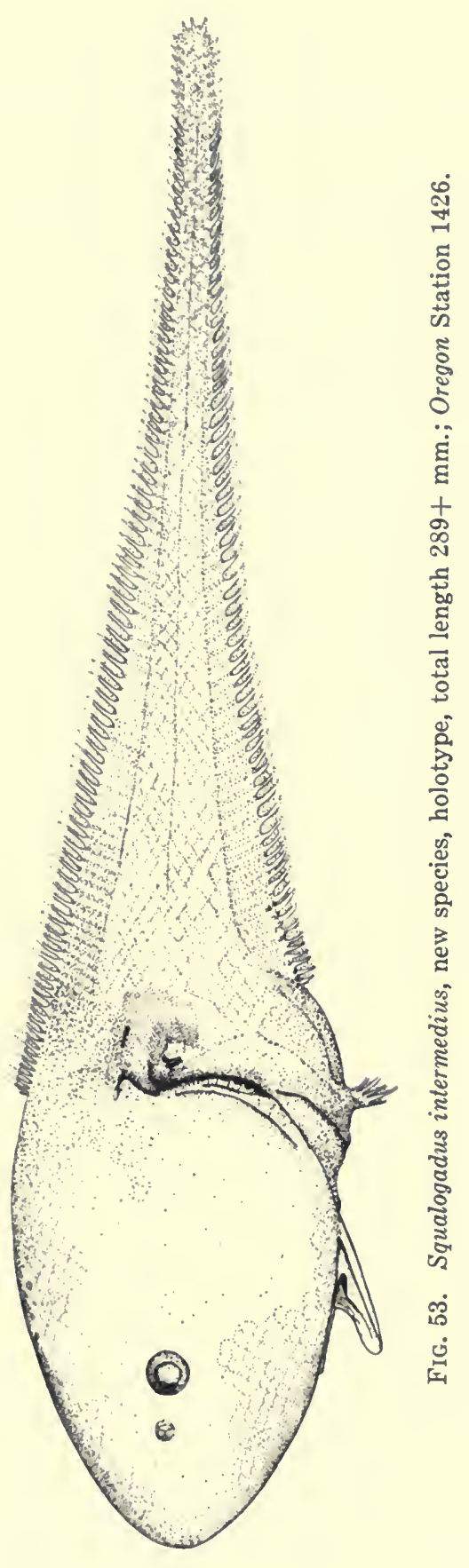


scale pockets apparent on branchiostegal membranes. On body, behind upper edge of gill opening, a few (about six) very small black papillae that apparently represent the lateral line, which is not otherwise visible.

Color of body and fins brown, belly blackish. Head darker, skin black beneath scales. Under side of head, branchiostegal membranes, inside of mouth and gill covers, and peritoneum black.

Remarks.-The discovery of a second species of the genus Squalogadus requires the deletion of the following phrases from the original generic diagnosis (Gilbert and Hubbs, 1916, p. 156): "mouth wholly behind orbit" and "short pseudobranchiae." In all other characters $S$. intermedius is congeneric with S. modificatus Gilbert and Hubbs. Specifically the new species differs in lacking pseudobranchiae, in the relative positions of eye and mouth, in a more compressed and slender body, a less rounded snout, and shorter maxillary and pre-oral lengths. In appearance $S$. intermedius is somewhat similar to the related form Macrouroides inflaticeps Smith and Radcliffe, hence its specific name.

The family Macrouroididae was erected by Radcliffe (1912, p. 138) for the genus Macrouroides Smith and Radcliffe. Upon the discovery of Squalogadus, Gilbert and Hubbs (1916, p. 156) reduced the family to a subfamily, Macrouroidinae, of the family Macrouridae. Berg (1940, p. 458) considered the relationships of the two genera uncertain and retained the family Macrouroididae.

TABLE 1.-Counts and Proportions of Squalogadus intermedius, new sp.

\begin{tabular}{|c|c|c|c|c|}
\hline \multirow[b]{2}{*}{ Total length (mm.). } & \multirow{3}{*}{$\begin{array}{c}\text { Holotype } \\
289+ \\
117\end{array}$} & \multicolumn{3}{|c|}{ Paratypes } \\
\hline & & 287 & $284+$ & 285 \\
\hline Snout to anus (mm.) & & 147.5 & 127.5 & 106 \\
\hline ectoral rays. & 26 & & 26 & 26 \\
\hline ill rakers. & $8+20$ & $9+21$ & $7+21$ & $7+21$ \\
\hline
\end{tabular}

Percentage of distance between snout and anus

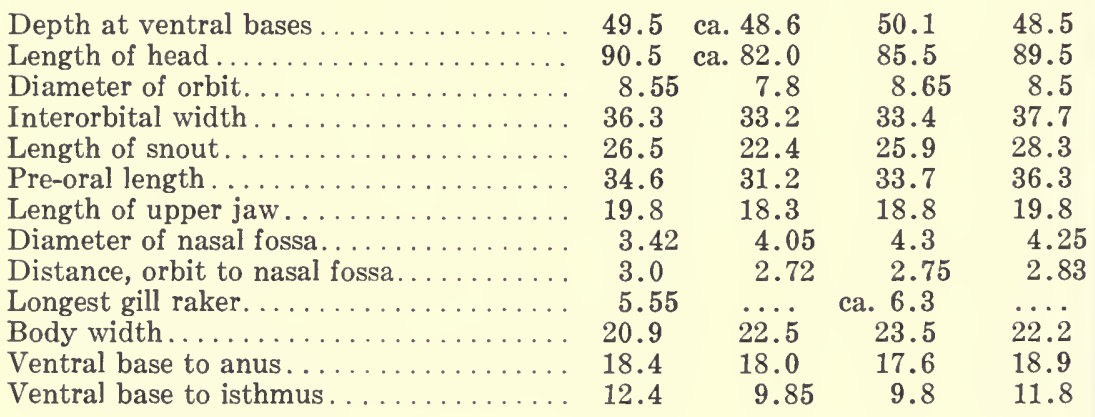


These fishes have been known heretofore only in the north Indian and western Pacific oceans and only five specimens have been reported. Macrouroides inflaticeps is known from the type, $147 \mathrm{~mm}$. long, from a depth of 408 fathoms (747 meters) in Lagonoy Gulf, Luzon, Philippine Islands; a specimen from an unknown depth in the Indian Ocean off the Maldive Islands (Norman, 1939, p. 48); and one specimen taken by the Galathea in 4000 meters over a bottom depth of 4820 meters in the Indian Ocean between Madagascar and Mombasa (Grey, 1956, p. 92; Bruun, in Bruun, et al., 1956, p. 168). Squalogadus modificatus has been caught only once (two specimens, 124 and $327 \mathrm{~mm}$.), off Kyushu, Japan, in 720 fathoms (1316 meters).

Mr. Harvey R. Bullis, Jr. has written (in litt., 1957) that the published record of Squalogadus from Oregon station 22 is an error (Springer and Bullis, 1956, p. 60). The types were recorded in their publication as Squalogadus sp.

\section{Family TRACHICHTH YIDAE}

\section{Hoplostethus mediterraneus Cuvier}

One specimen, $71 \mathrm{~mm}$. (without caudal). Station $599,29^{\circ} 21.7^{\prime} \mathrm{N}$., $87^{\circ} 29.8^{\prime} \mathrm{W}$., July 11,1952 , in 200 fathoms (366 meters).

One specimen, $150 \mathrm{~mm}$. Station $1342,23^{\circ} 10^{\prime} \mathrm{N} ., 79^{\circ} 33^{\prime} \mathrm{W}$., July 16,1955 , in 280 fathoms (512 meters).

Two specimens, 69 and $62 \mathrm{~mm}$. Station $1565,29^{\circ} 11^{\prime} \mathrm{N}$., $88^{\circ} 02^{\prime}$ W., June 22, 1956, in 240 fathoms (438 meters).

\section{Family GIBBERICHTHYIDAE}

\section{Gibberichthys pumilus Parr}

One specimen, standard length $47 \mathrm{~mm}$. Station $1425,29^{\circ} 04^{\prime} \mathrm{N}$., $88^{\circ} 05^{\prime}$ W., September 24, 1955, in 500 fathoms (914 meters).

Description.-Dorsal V,9; anal IV,8; ventral I,5; pectoral ca. 14 . Caudal 8 , with 8 supplementary spiny rays above on the peduncle and 8 below. The following measurements are in millimeters: Depth 16.5; head 20.5; snout ca. 6 ; eye 5.5; interorbital 10; upper jaw 12; lower jaw 13; snout to dorsal origin 23.5 , to anal origin ca. 29 ; least depth of caudal peduncle 4.5 ; length of pectoral 11.5 , of ventral 5 .

Color entirely black. Specimen answering type description in all respects except that it has only five dorsal spines. Lateral scale count impossible, skin partially torn away. 
Remarks. - G. pumilus has not been caught before in the Gulf of Mexico and is, in fact, known from only two other specimens. The type was taken north of Haiti (ca. $21^{\circ} \mathrm{N}$., $72^{\circ} \mathrm{W}$.) in about 1400 meters, a second specimen off the Bahamas at a depth of 10501100 meters. The specimen described here was listed by Springer and Bullis (1956, p. 66).

TABLE 2.-Counts and Proportions of Gibberichthys pumilus

(Taken from the literature where indicated)

\begin{tabular}{|c|c|c|c|}
\hline & $\begin{array}{c}\text { Parr, } \\
\text { 1933, p. } 5\end{array}$ & Oregon & $\begin{array}{r}\text { Parr, } \\
\text { 1934, p. } 3\end{array}$ \\
\hline Standard length (mm.). & 91 & 47 & 31.5 \\
\hline Dorsal rays.......... & $\mathrm{V}+\mathrm{I}, 9$ & $\mathrm{~V}, 9$ & $\mathrm{VI}, 9$ \\
\hline Anal rays......... & $\mathrm{III}+\mathrm{I}, 8$ & IV, 8 & III, 9 \\
\hline Pectoral rays. . & 15 & ca. 14 & 14 \\
\hline 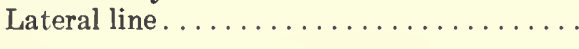 & 29 & - & 29 \\
\hline \multicolumn{4}{|c|}{ Percentage of standard length } \\
\hline$\ldots \ldots \ldots \ldots \ldots \ldots \ldots$ & 29.1 & 35.2 & 36.0 \\
\hline 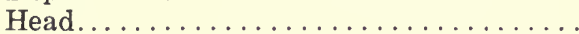 & 42.3 & 43.7 & 46.0 \\
\hline Snout $\ldots \ldots \ldots \ldots \ldots \ldots \ldots \ldots \ldots$ & 15.4 & ca. 12.8 & 13.0 \\
\hline$\ldots \ldots \ldots \ldots$ & 6.7 & 11.7 & 11.0 \\
\hline Interorbital width $\ldots \ldots \ldots \ldots \ldots \ldots \ldots$ & 17.0 & 21.3 & 18.0 \\
\hline Upper jaw. . . . . . . . . & 24.7 & 25.5 & 25.5 \\
\hline$\ldots \ldots \ldots \ldots \ldots \ldots, \ldots$ & 26.4 & 27.7 & 28.5 \\
\hline Snout to dorsal. & 51.0 & 50.0 & 57.0 \\
\hline Snout to anal. & 59.3 & ca. 62.0 & 61.0 \\
\hline Least depth of caudal peduncle. . . . . . . . . & 10.5 & 9.6 & 10.0 \\
\hline 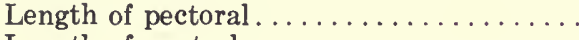 & 17.0 & 24.5 & 21.0 \\
\hline Length of ventral. & 9.3 & 10.6 & 8.0 \\
\hline
\end{tabular}

\section{Family ANOPLOGASTRIDAE}

Anoplogaster cornutus Valenciennes

One specimen, standard length ca. $118 \mathrm{~mm}$. Station 1425 , $29^{\circ} 04^{\prime}$ N., $88^{\circ} 05^{\prime}$ W., September 24,1955 , in 500 fathoms (914 meters).

This is not a new record. An earlier specimen was reported (Grey, 1955, p. 293) and the present specimen was listed by Springer and Bullis (1956, p. 67). The branchial region is greatly distorted, for the neck is dislocated. The specimen is brownish in color, and although the belly is darker the black ventral markings of the juvenile coloration are visible in front of the ventral bases and on the caudal peduncle just behind the anal fin. The fangs of both jaws are well developed and the upper jaw bears two other teeth on each side, the lower jaw three additional teeth. There are no small teeth anywhere except posteriorly on the lower jaw, and these are quite minute. 


\section{Family MELAMPHAIDAE}

\section{Melamphaes megalops Lütken}

One specimen, standard length $54 \mathrm{~mm}$. Station $1425,29^{\circ} 04^{\prime} \mathrm{N}$., $88^{\circ} 05^{\prime}$ W., September 24, 1955, in 500 fathoms (914 meters).

Description.-Dorsal 12; anal I,9. Lateral line ca. 30-32. Measurements in millimeters, followed in parentheses by percentage of the standard length (54 mm.): Depth 15 (27.8); head 20 (37.1); snout ca. 3.5 (ca. 6.5); eye 5 (9.25); tip of snout to dorsal origin 23 (42.6), to anal origin ca. $32.5(60.1)$, to ventral base ca. 17.5 (32.4); end of anal to base of middle caudal rays 17.5 (32.4); least depth of caudal peduncle 4.5 (8.35); length of pectoral fin 17 (31.4); length of ventral fin $12(22.2)$.

Spine present between eyes. No projecting spines or crests on head. Pectoral very long, reaching end of anal. Ventral long, reaching to vent (tip broken?), its origin slightly in front of pectoral base. Anal origin beneath a vertical slightly behind center of dorsal.

Remarks. $-M$. megalops had not been recorded from the Gulf of Mexico prior to the Oregon explorations (Springer and Bullis, 1956, p. 66) and is rarely reported in the western Atlantic (Beebe, 1937, p. 206, one specimen; Koefoed, 1953, p. 25, one specimen). It is also known from the central, eastern and southeastern Atlantic, off South Africa, in the Indian Ocean, and in the eastern Pacific.

\section{Family PERCOPHIDIDAE}

Genus Bembrops Steindachner

The genus Bembrops is almost cosmopolitan in warm waters at moderate depths. Apparently it contains a rather large number of species, of which three are found in the Gulf of Mexico. The various species have not always been clearly differentiated and the following characters, not mentioned in most published reports, may facilitate their distinction.

1. Course of anterior curve of lateral line, which is gradual in most species but quite abrupt in others, for example, gobioides.

2. Teeth in front of upper jaw; some of these are noticeably larger and curved, in some species, for example, anatirostris, but more or less uniformly minute in others, for example, gobioides and macromma. 
3. Vomerine and palatine teeth, which are uniformly minute in gobioides but include some larger, curved teeth in macromma and anatirostris.

4. Presence or absence of a small naked area in front of eye; the lower anterior portion of the orbit is obscured by a piece of tough skin, which is scaleless in gobioides and macromma but is entirely covered with reduced scales in anatirostris.

5. Relative length of maxillary flap.

The prolongation of one of the dorsal spines is found only in the male of anatirostris, and it is possible that other species may also exhibit sexual dimorphism.

The following key applies only to species known from the Gulf of Mexico and off the north coast of Cuba. Other forms found in the western Atlantic outside the Gulf will be treated at another time.

1a. Dorsal rays 16-18. Teeth on jaws, vomer and palatines minute. Downward curve of lateral line abrupt beneath anterior portion of first dorsal fin, lateral line reaching its lowest point beneath middle of pectoral and below end of first dorsal. [Lateral scale count $62-71.] \ldots \ldots \ldots \ldots \ldots \ldots \ldots$. . . . . . . . . . . . . . . .

1b. Dorsal rays 14-15. Vomer with some enlarged teeth and palatines with a row of curved teeth. Downward curve of lateral line gradual, lateral line reaching its lowest point beneath end of pectoral and below front of second dorsal.

2a. Anterior portion of upper jaw with a few teeth slightly enlarged, but not prominent. Lateral scale count (50?) 55-59. Small naked area in front of eye. Maxillary flap 1.4-1.9 per cent of standard length, 3.9-5.35 per cent of head ................................... ma

2b. Anterior portion of upper jaw with some enlarged, curved, prominent teeth. Lateral scale count 61-69. Area in front of eye covered with reduced scales. Maxillary flap 4.0-7.1 per cent of standard length, $10.2-18.3$ per cent of head . . . . . . . . . . . . . . . . anatirostris

Bembrops anatirostris Ginsburg. Figure 54.

One specimen, total length $155 \mathrm{~mm}$. Gulf of Mexico, $26^{\circ} 48^{\prime} \mathrm{N}$., $96^{\circ} 23^{\prime}$ W., October 27, 1951, in 200 fathoms (366 meters).

Six specimens, total length $130-243 \mathrm{~mm}$. Gulf of Mexico, $27^{\circ} 25^{\prime} \mathrm{N}$., $96^{\circ} 13^{\prime}$ W., November 27, 1950, in 76 fathoms (139 meters).

Four specimens, total length $190-261 \mathrm{~mm}$. Gulf of Mexico, $27^{\circ} 02^{\prime}$ N., $96^{\circ} 02^{\prime}$ W., July, 1952 , in 100 fathoms (183 meters).

Two specimens, total length $276,280 \mathrm{~mm}$. Gulf of Mexico, $27^{\circ} 15^{\prime}$ N., $96^{\circ} 15^{\prime} \mathrm{W}$., June, 1952, in ca. 200 fathoms (366 meters).

Nine specimens, total length $128-292 \mathrm{~mm}$. Station $156,27^{\circ} 22^{\prime} \mathrm{N}$., $96^{\circ} 08^{\prime}$ W., November 27, 1950, in 103 fathoms (188 meters).

Fifteen specimens, total length $119-300 \mathrm{~mm}$. Station 265 , $29^{\circ} 20^{\prime}$ N., $87^{\circ} 42^{\prime}$ W., February 16,1951 , in 101 fathoms (184 meters). 


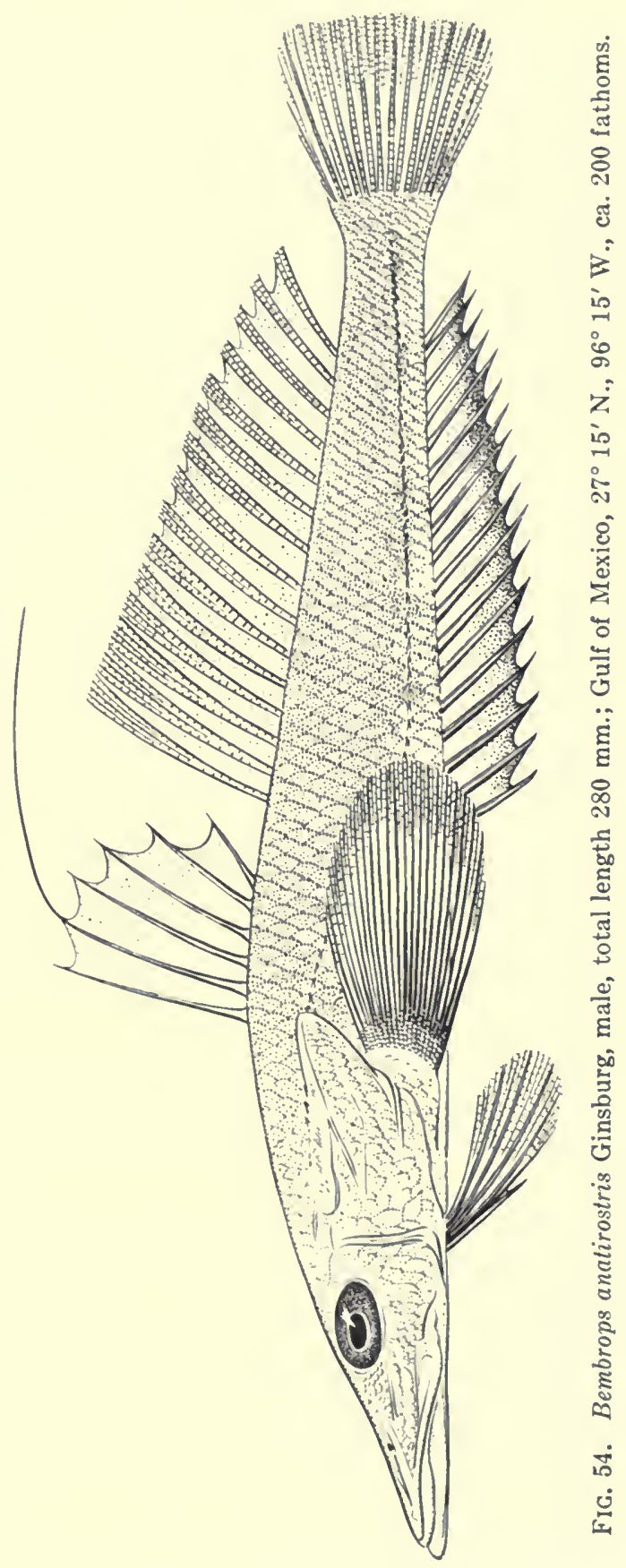


Three specimens, total length 213-274 mm. Station 269, $29^{\circ} 27.5^{\prime}$ N., $87^{\circ} 26.5^{\prime}$ W., February 17, 1951, in 150 fathoms (274 meters).

Five specimens, total length $125-232 \mathrm{~mm}$. Station $277,28^{\circ} 48^{\prime} \mathrm{N}$., $85^{\circ} 40^{\prime}$ W., February 23, 1951, in 104 fathoms (190 meters).

One specimen, total length $191.5 \mathrm{~mm}$. Station $696,29^{\circ} 44.2^{\prime} \mathrm{N}$., $87^{\circ} 08^{\prime}$ W., November 14,1952 , in 120 fathoms (220 meters).

Three specimens, total length $138.5-211 \mathrm{~mm}$. Station 733 , $28^{\circ} 50.2^{\prime}$ N., $85^{\circ} 43^{\prime}$ W., December 17,1952 , in 88 fathoms (161 meters).

One specimen, total length $284 \mathrm{~mm}$. Station $864,29^{\circ} 19^{\prime} \mathrm{N}$., $86^{\circ} 04^{\prime}$ W., October 31, 1953, in 82 fathoms (150 meters).

Description.-Dorsal VI,14-15; anal 17-19; pectoral 25-28. Lateral scale count 63-68. The following measurements are in percentages of the standard length (101.5-267 mm.): Depth 10.9-15.1 (three specimens 16.0, 16.7, 17.0); head 36.1-40.8 (mostly 38.0-39.0); tip of snout to origin of dorsal 35.0-39.4 (mostly 37.0-39.0); length of pectoral 22.0-25.1 (one specimen 29.8); length of prolonged second dorsal spine of male 22.1-33.1 (39.3 in one specimen); length of snout 10.6-12.5 (one specimen 9.1, one specimen 14.8); horizontal diameter of eye 7.6-9.4; length of upper jaw 13.0-15.3; length of maxillary flap 4.8-7.1 (one specimen 4.0). The following measurements are in percentages of the head length: Snout 28.4-31.4 (three specimens $24.8,27.8,32.2$ ) ; eye 19.7-24.0 (smaller in adult); upper jaw 36.239.3 ; maxillary flap $11.2-17.4$ (usually $13.0-17.0$; one specimen 10.2 , one specimen 18.3).

Downward curve of lateral line relatively long and gradual, lateral line reaching its lowest point beneath end of pectoral fin and below front of second dorsal fin. Soft dorsal and anal origins exactly opposite, or that of anal slightly more posterior. Upper caudal lobe larger than lower in some specimens.

Two rather indistinct large pores on naked margin of preopercle. In addition to the usual fleshy flap on end of maxillary, some specimens also with a smaller one, either above or below, at base of longer process. Area immediately in front of eye entirely covered with reduced scales. Jaw teeth in bands, mostly minute, but with larger, prominent, curved teeth anteriorly in upper jaw. Also some enlarged teeth among the vomerine teeth and a row of curved teeth on each palatine.

Male with second dorsal spine produced into a long filament, and with anal papilla larger than in female. Smallest identifiable male 
$168 \mathrm{~mm}$. standard length, with a short prolongation of second dorsal spine. Smallest identifiable female $171 \mathrm{~mm}$. standard length.

Color.-Nine or ten vague dark blotches on lateral line on sides and tail, these sometimes more distinct in smaller specimens. Both dorsals more or less dusky, membrane of first dorsal darker, prolongation of second spine black. Anal membrane blackish on edge, the rays pale. Caudal dusky with darker edges basally. Pectorals and ventrals more or less dusky. Pectoral bases and a strip forward along edges of isthmus silver. Peritoneum jet black. Inside of mouth and gill covers pale.

Remarks. - B. anatirostris resembles the Pacific B. filifera Gilbert rather closely, differing principally in having the second, rather than the first, dorsal spine produced in the male; in having this prolongation relatively much greater; and in the somewhat greater length of the maxillary flap. A direct comparison of the two forms might reveal further differences. This species is distinguished from gobioides and macromma in having a more posterior insertion of the dorsal fin, a longer maxillary flap, relatively longer head and snout, relatively smaller eye, enlarged teeth in the front of the upper jaw, and in lacking a scaleless area in front of the eye. From macromma it differs further in a higher scale count, and from gobioides in the more gradual curve of the lateral line, in having fewer dorsal rays, and in coloration.

$B$. anatirostris has been recorded previously from the Gulf of Mexico and off Puerto Rico, in 110-366 meters.

\section{Bembrops gobioides (Goode)}

Three specimens, total length $180-218 \mathrm{~mm}$. Station 266, $29^{\circ} 17.5^{\prime}$ N., $87^{\circ} 40^{\prime}$ W., February 16,1951 , in $185-200$ fathoms (338-366 meters).

Four specimens, total length $186.5-212 \mathrm{~mm}$. Station $270,29^{\circ} 23^{\prime} \mathrm{N}$., $87^{\circ} 25^{\prime}$ W., February 17, 1951, in 220 fathoms (403 meters).

Five specimens, total length $205-253 \mathrm{~mm}$. Station $272,29^{\circ} 16^{\prime} \mathrm{N}$., $86^{\circ} 39^{\prime}$ W., February 18, 1951, in 216 fathoms (395 meters).

Four specimens, total length $158-249 \mathrm{~mm}$. Station 472 or 484 , $29^{\circ} 05^{\prime}$ N., $88^{\circ} 31^{\prime}$ W., September 6, 1951, in 190 fathoms (348 meters) or $28^{\circ} 56.5^{\prime}$ N., $88^{\circ} 40^{\prime}$ W., September 7,1951 , in $220-240$ fathoms (403-438 meters).

One specimen, total length $228 \mathrm{~mm}$. Station $1011,24^{\circ} 28^{\prime} \mathrm{N}$., $83^{\circ} 25^{\prime}$ W., April 14, 1954, in 200 fathoms (366 meters). 
Description.-Dorsal VI,16-18; anal 17-18; pectoral 25-28. Lateral scale count 64-68. The following measurements are in percentages of the standard length (135-211 mm.): Depth 10.7-13.6 (one specimen 14.7); head 34.9-37.8 (33.7 in one specimen, 39.3 in another); tip of snout to origin of dorsal 33.1-37.5 (one specimen 40.0 ) ; length of pectoral 23.5-27.6 ; length of snout 10.1-12.3; horizontal diameter of eye 8.5-10.2; length of upper jaw 12.7-15.5; length of maxillary flap 2.3-3.48. The following measurements are in percentages of head length: Snout 28.4-33.2; eye 23.4-27.2; upper jaw 35.0-40.1; maxillary flap 6.5-9.7.

Downward curve of lateral line abrupt beneath anterior portion of first dorsal fin, the lateral line reaching its lowest point beneath middle of pectoral fin and below end of first dorsal. Anal origin slightly behind a vertical from origin of second dorsal.

Three conspicuous pores on exposed margin of preopercle. A small naked area in front of eye. Teeth minute, in bands on jaws, vomer and palatines; none enlarged.

Male differing from female in having a relatively larger anal papilla; that of female small and inconspicuous.

Color.-Vague dark markings on sides and tail. Membrane between first and second dorsal spines black, other membranes partially brown above. Membrane of second dorsal dark at base and edge, pale between. Anal membrane faintly dusky, the rays pale. Caudal with a black streak on lower and distal edges, and with a dark area basally above. Pectorals dusky. Ventrals pale. Some specimens with silver pigment on pectoral bases, extending to the ventrals but not forward on the isthmus as in anatirostris. Peritoneum black. Inside mouth and gill covers pale.

Remarks. $-B$. gobioides is compared with $B$. anatirostris on page 339. It differs from $B$. macromma as set forth in the key (p. 336), as well as in having smaller scales and a smaller maxillary flap, and in coloration. The anal fin of gobioides is a uniform, faintly dusky color; that of macromma is broadly edged in black.

B. gobioides has been recorded previously from the Gulf of Mexico and southern Florida, and once off New York, ca. $40^{\circ} \mathrm{N} ., 70^{\circ} \mathrm{W}$. Its depth range is $119-512$ meters.

Bembrops macromma Ginsburg. Figure 55.

Two specimens, total length $164,123 \mathrm{~mm}$. Station $1340,22^{\circ} 55^{\prime} \mathrm{N}$., $79^{\circ} 27^{\prime}$ W., July 15, 1955, in 240 fathoms (438 meters). 
Four specimens, total length $130-190 \mathrm{~mm}$. Station $1343,22^{\circ} 59^{\prime} \mathrm{N}$., $79^{\circ} 17^{\prime}$ W., July 16,1955 , in 250 fathoms (457 meters).

Description.-Dorsal VI,14; anal 18; pectoral 24-26. Lateral scale count probably 50-55. The following measurements are in percentages of the standard length (109-166 mm.), the first figure representing the largest specimen: Depth 12, 12.3, - , 11.5, 10.1, 12.4;

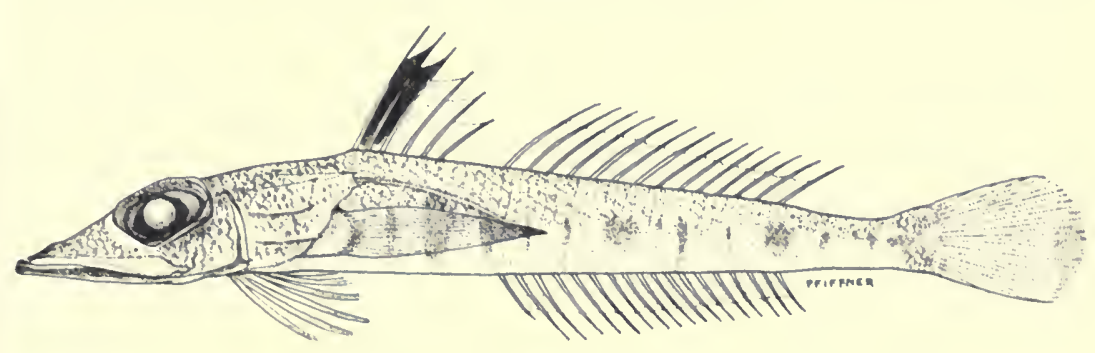

Fig. 55. Bembrops macromma Ginsburg, total length 188 mm.; Oregon Station 1343.

head $36.7,36.1,36.6,37.0,37.1,37.7$; tip of snout to origin of dorsal $33.7,33.9,36.3,36.7,32.5,36.3$; length of pectoral $23.8,23.8,24.0$, $22.2,13.5,23.8$; length of snout $9.65,9.7,9.35,10.4,8.8,10.1$; horizontal diameter of eye $9.95,9.35,9.35,10.0,9.7,10.1$; length of upper jaw 13.8, 14.2, 14.0, 14.7, 13.2, 14.2; length of maxillary flap (broken in some specimens) $-, 1.94,-, 1.44,1.76,-$. The following measurements are in percentages of head length: Snout 26.2, 26.8, 25.5, $28.2,24.4,26.8$; eye $27.1,25.9,25.5,27.2,26.8,26.8$; upper jaw 37.7 , 39.3, 38.2, 39.7, 36.5, 37.8; maxillary flap —, 5.35, —, 3.9, 4.9, —.

Downward curve of lateral line gradual, lowest point reached below end of pectoral fin and beneath front of second dorsal. Origins of soft dorsal and anal fins exactly opposite (anal commencing very slightly behind dorsal in one specimen).

Teeth minute, in bands on jaws, a few inner teeth in front of upper jaw slightly enlarged but not prominent. Vomer with a patch of teeth on each side, central row slightly enlarged. Palatines each with a single row of close-set curved teeth. A small naked area in front of eye.

Sex of specimens not known.

Color.-Exactly as described in the types (Ginsburg, 1955, p. 634) except that in the two smallest specimens, from station 1340 , the black anal margin is entirely lacking. Peritoneum black. Inside of mouth and gill covers pale. 
Remarks. - B. macromma is compared with the other two Gulf species on pages 339 and 340 . It has been reported previously only off the Virgin Islands in 548 and 274 meters. The specimens described above were recorded by Springer and Bullis (1956, p. 96).

\section{Family GEMPYLIDAE}

Epinnula orientalis americana Grey. Figure 56.

One specimen, $86 \mathrm{~mm}$. (without caudal). Station $1343,22^{\circ} 59^{\prime} \mathrm{N}$., $79^{\circ} 17^{\prime}$ W., July 16, 1955, in 250 fathoms (457 meters).

Three specimens, 219-235 mm. (without caudal). Station 1462 , $29^{\circ} 13^{\prime}$ N., $87^{\circ} 59^{\prime}$ W., February 22, 1956, in 200 fathoms (366 meters).

One specimen, $227.5 \mathrm{~mm}$. (without caudal). Station 1963, $29^{\circ} 11^{\prime}$ N., $88^{\circ} 03^{\prime}$ W., September 24, 1957, in 240 fathoms (438 meters).

The specimen from Station 1343, which was listed by Springer and Bullis (1956, p. 71), is apparently the smallest Epinnula on record. The following descriptive notes will allow a comparison with larger specimens:

Dorsal XVI,19; anal III,18. Proportions in percentages of the standard length $(86 \mathrm{~mm}$.): Depth 17.4; head 33.2; tip of snout to ventral base 40.1 ; end of anal fin to end of body 10.4; least depth of caudal peduncle 4.65 ; length of pectoral fin 16.3. Interorbital width shorter than diameter of eye. Greatest depth of body just behind head. Ventral origin beneath middle of pectoral fin. Lateral lines commencing together, beneath first dorsal spine. A few black chromatophores inside mouth anteriorly, inside of gill covers pale.

Figure 56 was drawn from the holotype.

\section{Promethichthys prometheus (Cuvier and Valenciennes)}

One specimen, $200 \mathrm{~mm}$. (without caudal). Station 1963, $29^{\circ} 11^{\prime} \mathrm{N}$., $88^{\circ} 03^{\prime}$ W., September 24, 1957, in 240 fathoms (438 meters).

One specimen, $272 \mathrm{~mm}$. (without caudal). Station $1964,29^{\circ} 14^{\prime} \mathrm{N}$., $87^{\circ} 53^{\prime}$ W., September 24, 1957, in 250 fathoms (457 meters).

One specimen, $273 \mathrm{~mm}$. (without caudal). Station $1968,29^{\circ} 13^{\prime}$ N., $88^{\circ} 00^{\prime}$ W., September 25, 1957, in 225 fathoms (411 meters).

One specimen, ca. $280 \mathrm{~mm}$. (without caudal). Station 1969, $29^{\circ} 10^{\prime}$ N., $88^{\circ} 11^{\prime}$ W., September 25, 1957, in 230-245 fathoms (421-448 meters). 


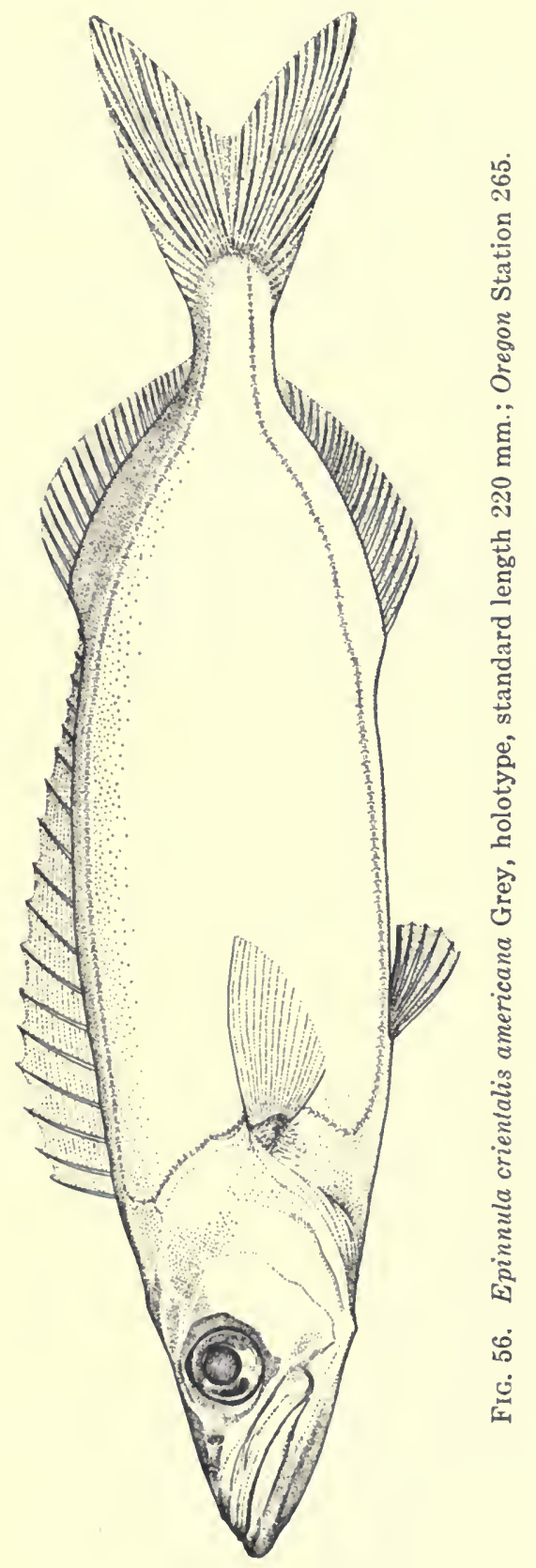




\section{Family BROTULIDAE}

\section{Neobythites gilli Goode and Bean}

Two specimens, 147 and $150 \mathrm{~mm}$. Station 1019, $24^{\circ} 16^{\prime} \mathrm{N}$., $83^{\circ} 22^{\prime}$ W., April 16, 1954, in 375 fathoms (686 meters).

Barathronus bicolor Goode and Bean. Figure 57.

Three specimens, total length 123,108 and $92+\mathrm{mm}$. Station not known, northeastern Gulf of Mexico, 1956, in 200-300 fathoms (366-548 meters).

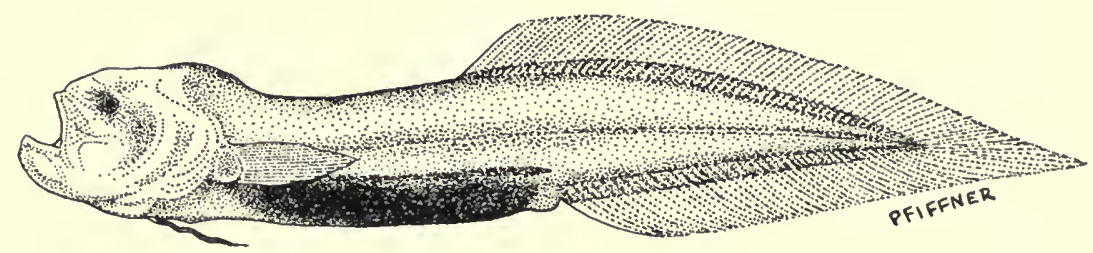

FIG. 57. Barathronus bicolor Goode and Bean, total length ca. $120 \mathrm{~mm}$.; Oregon Station 1908, Caribbean Sea.

These specimens differ from the type description in lacking the black lateral streak, only the belly being black. The outline of the head resembles that of $B$. diaphanus Brauer (1906, pl. 14, fig. 6) more closely than the figure of bicolor published by Goode and Bean (1895, fig. 298), nor do our specimens have prominent teeth as shown on that drawing. There are minute teeth in narrow bands in the upper jaw and anteriorly in the lower jaw. Posteriorly in the lower jaw, on each side, are four larger, widely spaced, sharp teeth but these are not fang-like. The vomer bears two relatively large teeth at each end and one or two smaller ones between, none of them fang-like. In other respects the specimens match the type description. The standard lengths of the two complete specimens are 106.5 and $95.5 \mathrm{~mm}$., and the largest has a dorsal and anal count of 69 and 55, respectively.

$B$. bicolor was described originally from a single specimen taken off Guadaloupe Island in the West Indies at a depth of 1408 meters. It has been recorded only twice since, once south of Tortugas, Florida, in either 307 or $540-576$ meters (one specimen) and off Cape Point, South Africa, in 1207 meters (one specimen). Also unrecorded are three specimens from the Caribbean Sea, Oregon Station 1908, $12^{\circ} 33^{\prime}$ N., $82^{\circ} 20^{\prime}$ W., September 11, 1957, in 350 fathoms $(640$ meters). These specimens are $88.5-97 \mathrm{~mm}$. in standard length; figure 57 was drawn from one of them. 


\section{REFERENCES}

BEEBE, W.

1937. Preliminary list of Bermuda deep-sea fish. Zoologica, 22: 197-208.

Beebe, W., and Crane, J.

1939. Deep-sea fishes of the Bermuda Oceanographic Expeditions. Family Melanostomiatidae. Zoologica, 24: 65-238, figs. 1-77.

BERG, L.

1940. Classification of fishes, both recent and fossil. Trav. Inst. Zool. Acad. Sci. U.S.S. R., 5: 87-517, 190 figs.

Brauer, A.

1906. Die Tiefseefische. 1. Systematischer Teil. Deutschen Tiefsee Exp. Valdivia, 15, (1), 432 pp., 18 pls., 176 text figs. Jena.

BruUn, A. F., et al.

1956. The Galathea deep sea expedition. 296 pp., illus. London.

Gilbert, C. H., and Hubis, C. H.

1916. Report on the Japanese macrourid fishes collected by the United States Fisheries Steamer Albatross in 1906, with a synopsis of the genera. Proc. U. S. Nat. Mus., 51: 135-214, pls. 8-11.

GILL, T.

1884. New families of fishes (Stephanoberycidae and Derichthyidae) recently added to the deep sea fauna. Amer. Nat., 18:433.

GinSBURG, I.

1955. Fishes of the family Percophididae from the coasts of the eastern United States and the West Indies, with descriptions of four new species. Proc. U.S. Nat. Mus., 104: 623-639, figs. 120-122.

GOODE, G. B., and BEAN, T. H.

1895. Oceanic Ichthyology. Smiths. Contr. Knowl., 981, 982, xxxv +553 pp., 417 figs.

Grey, M.

1955. Notes on a collection of Bermuda deep sea fishes. Fieldiana, Zool,, 37: 265-302, figs. 45-56.

1956. The distribution of fishes found below a depth of 2000 meters. Fieldiana, Zool., 36: 75-337.

HolT, E. W. L., and BYrNe, L. W.

1910. Third report on the fishes of the Irish Atlantic Slope. The Holocephali or chimaeras. Rep. Fish. Ireland 1908, Sci. Invest., 4: 1-26, 4 pls., 3 text figs.

KoEfoed, E.

1953. Synentognathi, Solenichthyes, Anacanthini, Berycomorphi, Xenoberyces from the Michael Sars North Atlantic Deep-sea Expedition 1910. Rep. Sci. Res. M. Sars No. Atl. Deep-sea Exp. 1910, 4, (2), (3), 38 pp., 4 pls., 6 text figs.

1956. Isospondyli. 1. Gymnophotodermi and Lepidophotodermi from the Michael Sars North Atlantic Deep-sea Expedition 1910. Rep. Sci. Res. M. Sars No. Atl. Deep-sea Exp. 1910, 4, (2), (5), 21 pp., 3 pls., 2 text figs.

NORMAN, J. R.

1939. Fishes. Sci. Rep. John Murray Exp. 1933-34, 7, (1), 116 pp., 41 figs. 



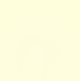

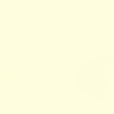


